\title{
Experience with minimum tillage and nitrogen fertilization
}

\author{
L. J. P. Kupers and J. Ellen
}

Department of Field Crops and Grassland Husbandry, Agricultural University, Wageningen, the Netherlands

Received: 5 October 1970

\section{Summary}

The results of nitrogen level experiments on ploughed and for years unploughed river clay soil show that soil tillage, ploughing, indeed has a favourable effect on the yield levels. Although quite acceptable yields can be obtained from unploughed soil with modern crop techniques, it has to be conceded that the response of the crops growing on these soils to increased nitrogen dressings decreases or is expressed in economically inattractive yields. We think that the explanation of this effect lies in the limited size and activity of the root system. The limited root system is promoted by the accumulation of chemical soil fertility factors in the upper layer of the topsoil, possibly stimulated by greater compactness of the topsoil of unploughed soil in the period when the plants develop their root systems.

\section{Introduction}

The interest of our Department in minimum tillage is in the response of the crop to this, in a way, new condition of the topsoil. Our interest is therefore centered especially around the question why crops do or do not respond to the complex of growing conditions which, within the scope of minimum tillage, are different from those we generally meet in the topsoil. Since 1957 an experiment has been set out in the fields of the department, in which the effect of very shallow cultivation instead of ploughing on the productivity of the crop and its weed flora are studied.

This report will deal with the lay-out and results of the trial, in which ploughing was omitted for fourteen years. By applying different nitrogen levels we have attempted to regulate the yield level.

\section{Experimental lay-out}

The trial field is laid out on a heavy river clay soil (Table 1). It is divided into two long strips: one strip which has not been ploughed since the lay-out in 1957, and an adjacent strip which is ploughed each year. Normal ploughing depth is 18 to $25 \mathrm{~cm}$ and depends on season and crop. Other tillage and cultivation techniques are carried out in the same way and to the same extent on both strips. The lifting of sugar-beets and potatoes is mechanized. The stubble treatment and preparation of the seedbed of cereals is carried out with a spring-tooth cultivator. The following crop rotation was applied in the last 
MINIMUM TILLAGE AND NITROGEN FERTILIZATION

Table I Characteristics of the trial field

\begin{tabular}{cccc}
\hline Particles $<16 \mathrm{um}$ & $\mathrm{CaCO}_{3}(\%)$ & Humus (\%) & $\mathrm{pH}-\mathrm{KCl}$ \\
57 & 0.4 & 4.2 & 6.6 \\
\hline
\end{tabular}

five years: 1966 spring wheat, 1967 potatoes, 1968 winter wheat, 1969 sugar-beets, and 1970 spring wheat.

The application of farm-yard manure and fertilizers, and the number and kind of chemical weed control applications were the same for both strips.

In both strips, plots were set out since 1968 to study the effect of nitrogen dressings. These plots are of such a size that possible residual effects of these nitrogen fertilizer plots in the successive crops can be avoided.

\section{Survey of the results}

In 1968 a nitrogen level and application time trial was set out in the winter wheat variety 'Manella'. The experimental scheme on each of the two strips, ploughed and unploughed, was a Latin square with three nitrogen levels; combined with the two application times the following variants were applied:

1. $\mathrm{N}_{1}: 57.5 \mathrm{~kg} \mathrm{~N} / \mathrm{ha}$ on $6 / 3 / 68$ at the beginning of growth in spring;

2. $\mathrm{N}_{2}: 57.5 \mathrm{~kg} \mathrm{~N} / \mathrm{ha}$ on $6 / 3 / 68+23 \mathrm{~kg} \mathrm{~N} / \mathrm{ha}$ in the 10.1 stage of the development stages of Feekes (beginning of flowering);

3. $\mathrm{N}_{3}: 57.5 \mathrm{~kg} \mathrm{~N} / \mathrm{ha}$ on $6 / 3 / 68+46 \mathrm{~kg} \mathrm{~N} / \mathrm{ha}$ in the 10.1 stage. The 10.1 stage was observed on $28 / 5 / 68$.

Table 2 shows the grain yields.

The unploughed strip apparently attained its maximum production already at the lowest and also earliest $\mathrm{N}$ application. The ploughed strip at the same $\mathrm{N}$ application has a higher production level, but apparently can also utilize the nitrogen applied as a late top dressing.

In 1969 sugar-beets were grown as an experimental crop. In the autumn of 1968 both strips were fertilized with 30 tons of farm-yard manure per ha, which together with the wheat stubble were incorporated somewhat into the top layer by a cultivator.

After spring application of $725 \mathrm{~kg}$ superphosphate per ha and $400 \mathrm{~kg} \mathrm{~K} 40, \mathrm{~N}$ level experiments were set out again with the following variants:

$\mathrm{N}_{1}: 30$ tons of farm-yard manure per ha

$\mathrm{N}_{2}: 30$ tons of farm-yard manure $+60 \mathrm{~kg} \mathrm{~N} / \mathrm{ha}$ as ammonium nitrate lime

$\mathrm{N}_{3}: 30$ tons of farm-yard manure $+120 \mathrm{~kg} \mathrm{~N} / \mathrm{ha}$ as ammonium nitrate lime

$\mathrm{N}_{4}: 30$ tons of farm-yard manure $+180 \mathrm{~kg} \mathrm{~N} / \mathrm{ha}$ as ammonium nitrate lime.

Table 2 Grain yield in $\mathrm{kg}$. ha-1 (16\% moisture); winter wheat, 1968

\begin{tabular}{ccccccc}
\hline & \multicolumn{3}{c}{ Unploughed } & & \multicolumn{3}{c}{ Ploughed } \\
\cline { 1 - 3 } \cline { 5 - 6 }$N_{1}$ & $N_{2}$ & $N_{3}$ & & $N_{1}$ & $N_{2}$ & $N_{3}$ \\
5127 & 5091 & 5084 & & 5556 & 5864 & 6002 \\
\hline
\end{tabular}


Table 3 Root yield and sugar yield of sugar-beet

\begin{tabular}{|c|c|c|c|c|c|c|c|c|}
\hline & \multicolumn{4}{|c|}{ Unploughed } & \multicolumn{4}{|c|}{ Ploughed } \\
\hline & $N_{i}$ & $N_{2}$ & $N_{3}$ & $N_{t}$ & $N_{1}$ & $N_{2}$ & $N_{3}$ & $N_{t}$ \\
\hline $\begin{array}{l}\text { Root yield } \\
(1000 \mathrm{~kg}, \mathrm{ha}-1)\end{array}$ & 38.1 & 49.6 & 54.7 & 54.9 & 48.6 & 60.0 & 65.1 & 63.8 \\
\hline $\begin{array}{l}\text { Sugar yield } \\
(\mathrm{kg}, \mathrm{ha}-1)\end{array}$ & 7057 & 8976 & 9946 & 9489 & 9279 & 11349 & 12495 & 11794 \\
\hline
\end{tabular}

Table 4 Branching of roots as percentages of numbers

\begin{tabular}{lccccccccc}
\hline Grade of branching & \multicolumn{4}{c}{ Unploughed } & \multicolumn{3}{c}{ Ploughed } \\
\cline { 2 - 5 } \cline { 6 - 9 } & $N_{1}$ & $N_{2}$ & $N_{3}$ & $N_{4}$ & & $N_{1}$ & $N_{2}$ & $N_{3}$ & $N_{4}$ \\
Not branched & 35.3 & 26.6 & 28.0 & 24.2 & & 61.3 & 51.3 & 60.2 & 56.4 \\
Branched & 25.3 & 19.0 & 18.0 & 23.0 & & 20.3 & 22.1 & 15.8 & 20.0 \\
Severely branched & 39.4 & 54.4 & 54.0 & 52.8 & & 18.4 & 26.1 & 24.0 & 22.6 \\
\hline
\end{tabular}

The ammonium nitrate lime was applied before sowing. Table 3 show the main aspects of the yields.

With a view to the nature of this trial Table 4 is especially important.

In discussing the results a few other aspects of this sugar-beet experiment will also be treated.

In 1970 both strips were grown with spring wheat, variety 'Orca', date of sowing 20/4/70. The nitrogen applications were, respectively: $\mathrm{N}_{1}=46 \mathrm{~kg} \mathrm{~N} / \mathrm{ha} ; \mathrm{N}_{2}=60 \mathrm{~kg} \mathrm{~N} / \mathrm{ha}$; $\mathrm{N}_{3}=90 \mathrm{~kg} \mathrm{~N} / \mathrm{ha} ; \mathrm{N}_{4}=120 \mathrm{~kg} \mathrm{~N} / \mathrm{ha}$.

These dressings were applied immediately after emergence of the crop. Table 5 shows the grain yields.

In general, the yields of this spring wheat were disappointing, very likely because of the late sowing date. Moreover, the late initial development was adversely affected by high temperatures during six weeks in May and the beginning of June, so that tillering of this crop was poor.

\section{Discussion of the results}

We are rather fortunate in that, at the time this experimental field was laid out on a heavy river clay soil. Indeed, the topsoil of heavy clay will be compacted when it has

Table 5 Grain yield in $\mathrm{kg} \cdot \mathrm{ha-1}$ (16\% moisture); spring wheat 1970

\begin{tabular}{ccccccccc}
\hline \multicolumn{3}{c}{} & \multicolumn{3}{c}{ Unploughed } & & & \multicolumn{4}{c}{ Ploughed } \\
\cline { 6 - 9 }$N_{1}$ & $N_{3}$ & $N_{1}$ & $N_{3}$ & & $N_{2}$ & $N_{4}$ & $N_{2}$ & $N_{4}$ \\
3080 & 3165 & 3272 & 3542 & & 3534 & 3417 & 3577 & 3715 \\
\hline
\end{tabular}


MINIMUM TILLAGE AND NITROGEN FERTILIZATION

Table 6 Pore space in $\%(v / v)$, measured 20/7/70

\begin{tabular}{lcc}
\hline $\begin{array}{l}\text { Depth of the } \\
\text { layer }\end{array}$ & Unploughed & Ploughed \\
$1-6 \mathrm{~cm}$ & 58.6 & \\
$6-11 \mathrm{~cm}$ & 50.4 & 58.2 \\
$11-16 \mathrm{~cm}$ & 49.7 & 55.4 \\
$16-21 \mathrm{~cm}$ & 49.9 & 56.0 \\
& & 56.0 \\
\hline
\end{tabular}

not been ploughed for over ten years, but on the other hand the annual effect of drying out alternated by water penetration into the soil will also allow the formation of some soil structure. The ploughed strip, however, annually runs the risk of plough-pan formation, when in ploughing the soil is so wet that the soil aggregates are puddled.

We do not have detailed data to illustrate the differences in soil structure of the two experimental strips. On the unploughed strip in November 1968 pore space was $48.5 \%$ $(\mathrm{v} / \mathrm{v})$ and air content at $\mathrm{pF} 2$ was $5.8 \%(\mathrm{v} / \mathrm{v})\left(50\right.$ samples of $\left.100 \mathrm{~cm}^{3}\right)$. Table 6 gives the differences in pore space between the ploughed and unploughed strip in 1970. Over the years we analysed many soil samples to gain some idea of the changes in the chemical soil fertility properties. Table 7 shows a survey of the most recent soil analysis, divided into two layers: the $0-10 \mathrm{~cm}$ layer and the $10-20 \mathrm{~cm}$ layer of the topsoil.

From these analysis results it may be inferred that variant 'unploughed' has led to distinct accumulation of chemical soil fertility properties in the upper $10 \mathrm{~cm}$ of the topsoil. The P-Al value and the $\mathrm{K}$ content are higher, and so is the organic matter content in this layer. Analysis results, not mentioned in this report, show that the $C / N$ ratio in the organic matter is about equal in the ploughed as well as in the unploughed soil.

Besides being affected by soil fertility factors, the yield of a crop is dependent on climatological factors occurring during the growing period. Table 8 is an attempt at giving a survey of the weather in the three successive trial years.

After this brief outline of pedological and climatic factors, we return to the results of the trials. We suggest to base the discussion on the assumption that on the unploughed strip the root system of the crops is limited in size and in activity.

Table 4, outlining the extent of branching in sugar-beets, is a very distinct point in support of this assumption. However the causes of the hampered root growth on the unploughed soil are difficult to determine definitely. Compacting as well as the rather abrupt change from layers very rich in chemical factors to less rich layers in the topsoil may cause this effect. Very likely, the superficially incorporated farm-yard manure may also have increased the percentage of branched sugar-beets.

Table 7 Chemical analysis of soil fertility factors (1969)

\begin{tabular}{|c|c|c|c|c|c|c|c|}
\hline Layer & & $p H K C l$ & $\begin{array}{l}\text { Organic matter } \\
\text { elem. }\end{array}$ & $\begin{array}{c}\mathrm{CaCO}_{3} \\
(\%)\end{array}$ & $\begin{array}{c}\text { Phosphate } \\
\text { as } P-A l\end{array}$ & $\begin{array}{l}\text { Potash } \\
\text { as } K \%\end{array}$ & Total $N$ \\
\hline \multirow[t]{2}{*}{$0-10 \mathrm{~cm}$} & Unploughed & 5.8 & 5.4 & 0.1 & 70 & 44 & 0.26 \\
\hline & Ploughed & 5.9 & 4.2 & 0.1 & 51 & 26 & 0.21 \\
\hline \multirow[t]{2}{*}{$10-20 \mathrm{~cm}$} & Unploughed & 6.3 & 4.3 & 0.1 & 39 & 22 & 0.22 \\
\hline & Ploughed & 6.1 & 4.2 & 0.1 & 38 & 21 & 0.22 \\
\hline
\end{tabular}


Table 8 Characteristics of the weather in the growing periods in 1968, 1969 and 1970

\begin{tabular}{|c|c|c|c|c|c|c|c|c|c|c|}
\hline \multirow{3}{*}{$\begin{array}{l}\text { Temperature: } \\
\text { Rainfall: }\end{array}$} & \multicolumn{4}{|c|}{ Spring } & \multicolumn{3}{|c|}{ Summer } & \multicolumn{3}{|c|}{ Autumn } \\
\hline & normal & $w a$ & & cold & normal & warm & cold & normal & warm & cold \\
\hline & $d w$ & $d$ & $w$ & $d w$ & $d \quad w$ & $d w$ & $d w$ & $d w$ & $d w$ & $d w$ \\
\hline 1968 & & & $\mathrm{x}$ & & $x x$ & & & $\mathrm{xx}$ & & \\
\hline 1969 & & & & $\mathrm{x}$ & & $x$ & & & $\mathrm{x}$ & \\
\hline 1970 & & & & $\mathbf{x x}$ & & $\mathbf{x}$ & & & & \\
\hline
\end{tabular}

$\mathrm{d}=\mathrm{dry} ; \mathrm{w}=$ wet. Data obtained from the Netherlands Meteorological Institute, De Bilt, the Netherlands.

If we assume that both cereal crops also formed a limited and superficial root system on the unploughed strip, how are we to explain the different reponses to the $\mathrm{N}$ applications.

The response of the winter wheat in the trial year 1968, according to plant analysis at the harvest, was as follows (Table 9). These analysis results correspond well with the assessments for lodging in the winter wheat (Table 10).

In the very wet summer of 1968 the wheat on the unploughed strip could not completely utilize the larger nitrogen applications with the result of lodging. This aspect is also shown by the decreasing 1000 -kernel weights.

However it remains a question why the wheat on the ploughed strip could utilize the higher $\mathrm{N}$ applications and why the crop hardly showed any lodging.

It may be assumed that the crop with the limited root system, in a wet year (1968), will not have suffered from a water deficit. However nitrogen nutrition of a crop in these cases is rather erratic. In the beginning of growth the nitrogen supply will be liberal, leading to apparently prosperous growth of the crop. Even applications of only $57.5 \mathrm{~kg} \mathrm{~N} / \mathrm{ha}$, in proportion to the superficial depth of the unploughed topsoil, ap-

Table 9 Yield analysis of winter wheat in 1968

\begin{tabular}{|c|c|c|c|c|c|c|}
\hline & \multicolumn{3}{|c|}{ Unploughed } & \multicolumn{3}{|c|}{ Ploughed } \\
\hline & $N_{1}$ & $N_{2}$ & $N_{n}$ & $N_{i}$ & $N_{2}$ & $N_{3}$ \\
\hline 1000 -grain weight & 40.6 & 39.3 & 38.3 & 40.0 & 41.6 & 43.1 \\
\hline Number of grains per ear & 22 & 27 & 31 & 27 & 30 & 31 \\
\hline
\end{tabular}

Table 10 Estimated values for lodging of winter wheat in 1968

\begin{tabular}{ccccccc}
\hline \multicolumn{3}{c}{ Unploughed } & & & \multicolumn{3}{c}{ Ploughed } \\
\cline { 1 - 3 } \cline { 5 - 7 }$N_{1}$ & $N_{2}$ & $N_{3}$ & & $N_{1}$ & $N_{2}$ & $N_{3}$ \\
7.6 & 6.6 & 6.6 & & 9.6 & 8.0 & 9.0 \\
\hline
\end{tabular}

$1=$ severe lodging $\ldots 10=$ erect. 
Table 11 Dry-matter production in $1000 \mathrm{~kg}$.ha-1 and the distribution of dry matter over the parts of the plants in \% of total dry matter; sugar-beet, 1969

\begin{tabular}{|c|c|c|c|c|c|c|c|c|}
\hline & \multicolumn{4}{|c|}{ Unploughed } & \multicolumn{4}{|c|}{ Ploughed } \\
\hline & $N_{1}$ & $N_{2}$ & $N_{3}$ & $N_{4}$ & $N_{t}$ & $N_{2}$ & $N_{3}$ & $N_{4}$ \\
\hline \multicolumn{9}{|l|}{ Absolute weights } \\
\hline Leafs & 1.58 & 1.97 & 2.28 & 2.44 & 1.65 & 2.13 & 2.33 & 2.28 \\
\hline Stems & 1.19 & 1.42 & 1.55 & 1.96 & 1.23 & 1.74 & 2.09 & 2.37 \\
\hline Roots + crown & 10.21 & 13.04 & 13.73 & 14.64 & 12.45 & 15.95 & 17.32 & 16.87 \\
\hline Total dry matter & 12.98 & 16.43 & 17.56 & 19.04 & 15.33 & 19.80 & 21.74 & 21.52 \\
\hline \multicolumn{9}{|l|}{ As \% of total DM } \\
\hline Leafs & 12.2 & 12.0 & 13.0 & 12.8 & 10.8 & 10.7 & 10.7 & 10.6 \\
\hline Stems & 9.2 & 8.6 & 8.8 & 10.3 & 8.0 & 8.8 & 9.6 & 11.0 \\
\hline Roots + crown & 78.6 & 79.4 & 78.2 & 76.9 & 81.2 & 80.5 & 79.7 & 78.4 \\
\hline
\end{tabular}

parently is a high application. The same argument may also explain the negative effect of the late top dressing. The superficial root system of the wheat crop may very rapidly establish contact with the nitrogen fertilizer penetrating into the upper layer of the topsoil. This dose is indeed applied only in the heading stage of the crop but this does not mean that the rapidly absorbed nitrogen cannot have a morphological or anatomical effect on the plants at that stage.

The sugar-beet crop in 1969 showed a different response to the different nitrogen levels. Plant analysis (Table 11) shows that the differences in yield between the unploughed and ploughed strips in terms of total dry matter can be compensated by high nitrogen applications. The variant $\mathrm{N}_{4}$ 'unploughed' is almost as productive as the variant $\mathrm{N}_{2}$ 'ploughed'.

The most characteristic difference in productivity of the crops on the unploughed and ploughed strips is, however, the distinctly unfavourable distribution of dry matter on the unploughed strip.

The unploughed $\mathrm{N}$ levels show the well known effect of heavy $\mathrm{N}$ applications on sugar beets, viz the unfavourable leaf/root ratio, already from the $N_{1}$ level onwards i.e. only nitrogen supply from the farm-yard manure.

During the dry and hot months of June and July the beets on the unploughed strip stood sleeping regularly in the afternoons, and all the more so as the nitrogen application had been lower. The proportionally great leaf cover formed on the unploughed strip indicates that the crop had too little opportunity to store the dry matter formed in the roots.

We consider that the small and inactive root system prevented the crop on the unploughed strip from taking up enough water for unhampered dry-matter production in the hot summer of 1969.

The average lower total dry-matter production on the unploughed strip was moreover converted to leaves under influence of the liberal nitrogen application.

The spring wheat in the trial year 1970 developed under special conditions. The crop was sown very late compared to normal years. Initial growth was slow. In May and in the beginning of June temperatures rose to far above normal. As a result of the prevailing long period of high evapotranspiration the crop had a very short straw length, although on account of the prevailing high temperatures a long and weak straw 
Table 12 Stage of ripening of spring wheat, 20/8/70 (10 is fully ripe)

\begin{tabular}{|c|c|c|c|c|c|c|c|}
\hline \multicolumn{4}{|c|}{ Unploughed } & \multicolumn{4}{|c|}{ Ploughed } \\
\hline$N_{1}$ & $N_{2}$ & $N_{3}$ & $N_{4}$ & $N_{t}$ & $N_{\Xi}$ & $N_{3}$ & $N_{4}$ \\
\hline 8.8 & 7.8 & 7.0 & 6.5 & 7.3 & 5.3 & 6.0 & 5.0 \\
\hline
\end{tabular}

might have been expected. During flowering a cold wet period started. Grain setting and ripening, on the other hand, occurred again in good summer weather.

Although at this moment we have not a detailed analysis report available, a tentative conclusion is that on account of the special weather conditions in 1970 this crop of spring wheat had only a small opportunity of taking up nitrogen, when it could have been efficiently used in growth of the plant, viz during the formation of organs. Table 12 shows an assessment of the extent of ripening on $22 / 8 / 70$.

The rate at which the different variants ripened, i.e. lost moisture and dried, was found to be related to the soil tillage variants and to the nitrogen applications. 